Кудрявцев М.Г. доктор філологічних наук, професор Кам'янещь-Подільський начіональний університет ім. I. Огієнка

\title{
КОМЕДІЯ ЯК ДРАМАТУРГІЧНИЙ ЖАНР: ГЕНЕЗА, МОДИФІКАЦЇ̈, ТЕНДЕНЦІЇ ТА ЯВИЩА
}

У статті простежуються проблема комедійного жанру, його еволючія, різновиди, модифікачії у вітчизняній і світовій класиџі на всіх етапах культурноісторичного розвитку.

Ключові слова: жанри, комедія, конфлікт, ситуачія, тенеза, трагікомічне, характери.

В статье рассматриваются проблема комедийного жанра, его эволючия, разновидности, модификачии в украинской и мировой классике на всех этапах культурно-исторического развития.

Ключевые слова: жанры, комедия, конфликт, ситуачия, генезис, трагикомическое, характеры.

The article studies the problem of comedy, its evolution, varieties, modifications in the native and world classics at all stages of cultural-historical development.

Key words: genres, comedy, conflict, situation, genesis, tragicomic, characters.

Категорія комічного в літературі осмислюється 3 давніхдавен, починаючи з Арістотеля: життєві факти та явища можна розглядати як «серйозно», так і комічно (комічне походить від 
грецького Komi Kos - веселий, смішний; Komos - весела ватага празниково наряджених на свята в честь бога Діоніса у Стародавній Греції).

Звідси і генеза комедії як жанру, що постав в античній Греції із сороміцьких пісень.

Комедія (від лат. Comoedia, грецького Komodia, від komos весела процесія й ode - пісня) - вид драматургічного твору, у якому характери, ситуації та дія представлені у смішних формах, пройняті комізмом: за визначенням Арістотеля, це наслідування гіршого в людях, не у всіх їх негативностях, а в смішному вигляді. До епохи Класицизму комедія розглядалась як твір протилежний трагедії, з обов'язковим щасливим фіналом. На противагу трагедійному жанру персонажі комедії, як правило, мали бути із нижчих соціальних прошарків. Поетика класицизму і визначала комедію поряд з байкою як «низький жанр» (відповідно трагедія, поема, ода відносились до жанрів високих). Драматичні твори, у яких джерелом смішного $є$ ситуації, обставини, що склалися, відносять відповідно до комедій ситуацій. Існують комедії, де смішне закладене в самій сутності людського характеру, моральних імперативів, де гіпертрофовані до комічного сприйняття пороки суспільства і конкретного індивіда. Саме такі комедії часто несуть у собі яскраво виражені сатиричні ознаки, висміювання найпотворнішого в людині.

Взагалі жанрово-тематичний спектр комедій досить широкий. Це й антична комедія (присвячена Діонісу культова п'єса, яку виконують хор та актори), й комедія-балет (драматична форма створена Мольєром, який включав у дію балетні сцени), й побутова комедія на теми повсякденного життя, й комедія масок, або комедія дель арте - власне італійські імпровізації за коротким літературним сценарієм (персонажами такої комедії виступали маски - «слуги» Брігелла, Арлекін, Серветта, Пульчинелла, купець Панталоне, Капітан, Доктор тощо, які зазвичай переходили з одного спектаклю в інший, діалоги грунтувались на народних діалектах, елементами поетики цих імпровізацій були передусім гротеск, буфонадні засоби, 
музичність, карнавальність та ін.), комедія ідей (п'єси, у яких домінували дискусії, обговорювання різних популярних теорій та ідей: такі комедії-дискусії ставали пріоритетними в епоху модернізму Бернард Шоу, А. Чехов, М. Куліш тощо), комедія інтриги чи комедія становища (твори зі складними сюжетами з декількома лініями й різними, непередбаченими поворотами), комедія «плаща і шпаги» (іспанський різновид жанру), сатирична комедія, де розвінчуються суспільні та людські пороки, слізлива, сентиментальна комедія, яка мала морально-дидактичний характер (відповідно, зворушливі сцени тут витісняли комічне начало), учена комедія (такий жанр був розповсюджений в Італії в XVI ст., він базувався на використанні традицій гостросюжетної італійської новелістики, яскравим прикладом таких новел може бути «Декамерон» Дж. Боккаччо) тощо.

Родоначальником комедії вважається античний класик Арістофан, який жив близько 445-385 рр. до н. е.

Комедії ситуацій Арістофана порушували суспільні, моральні, політичні, естетичні проблеми не тільки свого часу.

Афористичністю, глибинним підтекстом, метафоричністю образів вони й сьогодні зберігають ідейно-художню ефектність і суспільну актуальність.

Традиції Арістофана мали місце в новоантичній літературі, зокрема в Менандра, й у творчості римських митців (Теренцій, Плавт), де увага зосереджувалась передусім на питаннях приватнопобутового, світського життя.

В епоху Середньовіччя сміхове начало реалізовувалось переважно в карнавальних дійствах, проникаючи і в середовище релігійних жанрів. На розвиток європейського театру мали вплив італійська «учена комедія», популярна в XVI ст., і комедія масок (комедія дель арте), які успадкували передусім римські традиції.

Жанр комедії досяг розквіту в різноманітних проявах у гуманістичну епоху. Популярністю користувались твори іспанських драматургів Лопе де Веги («Собака на сіні», «Учитель танців») i Кальдерона, який не без впливу першого створив комедії «плаща і 
шпаги» «Кохання, честь і влада», «Гра кохання та долі», «Удаваний звіздар», «Дама-невидимка», «У тихому болоті» тощо - твори, які відносять до комедії інтриги, де імпульсивне начало в розгортанні колізій, заплутаності в розвитку дії належить жінкам. Цим комедіям властиві гіпертрофована метафоричність, ліризм, поетизація мови персонажів, майстерність діалогів і монологів, які грають ключову роль у розкритті характерів.

У комедіях Лопе де Веги, вплив якого на творчість Кальдерона де ла Барки незаперечний, головна роль у закрученні інтриги належить слугам, які є серцевиною комічних ситуацій.

Вершиною здобутків жанру в епоху Відродження вважаються кращі твори В. Шекспіра - комедії настрою на любовну тематику, на яких відчувається безпосередній вплив як давньоримської комедіографії, так і «ученої» італійської комедії XVI ст.

Тут і цікава своїми гумористичними перипетіями п’єса «Віндзорські жартівниці», де виведений оригінальний образ невдахи рицаря Джона Фальстафа, що став у світовій класиці узагальнюючим типом, і класична феєрія «Сон літньої ночі», де земний світ переплітається з казковим, і чудова лірична історія любові й пошуку щастя в загадковій країні Іллірії (художній авторський вимисел) історія зі щасливою розв'язкою, з переплетенням інтриг «Дванадцята ніч» (твір цей у 50-х рр. здобув визнання як кінокласика прекрасна екранізація зі знаменитими акторами: А. Ларіоновою, К. Лучко, С. Лук $\square$ яновим, Л. Яншиним, Г. Віциним та ін.), і драма про виборене у випробуваннях кохання «Приборкання норовливої» (комедія має чудовий екранний варіант з виконавцями головних ролей Р. Бартоном та Е. Тейлор), і п'єса «Венеціанський купець»застережлива передусім загрозою кровожерливого лихварства, виведеного в образі Шейлока, що уособлює мстиву корисливість і жорстокість, які віками правлять світом, закабаляючи людину морально й фізично (шекспірівський Шейлок давно став узагальнюючим образом - образом кровожерливого лиходія, але лиходія водночас і трагічного, і комічного, і жахливого, і поліфонічного в дослідженні 
психологічних глибин, у спробі збагнути генезис лихварського зла). Переплітаючи комічне з трагічним, жахливе з життєрадісним, внутрішню красу з духовною потворністю, Шекспір у своїх кращих комедіях вміло поєднував викривальне сміхове начало з життєстверджуючим оптимізмом, веселістю. Характерно, що необхідність щасливих кінцівок відповідно до вимог жанру в комедіях Шекспіра не завжди окреслює відновлення справедливості, гармонії стосунків: пригадаймо і «Комедію помилок», i «Як це подобається», i «Венеціанського купця», i «Багато галасу даремно».

Класицистична естетика, що стала домінуючою в II половині XVII ст. та зберігала панівне начало і в епоху Просвітництва 3 їі раціоналізмом, пріоритетом розуму над почуттями, державницькими ідеями, громадянською пафосністю, моральним дидактизмом, визначала свої вимоги до комедійного жанру, який, згідно з канонами класицизму, належав до низьких і був покликаний висміювати ті пороки, що передусім наносили шкоду суспільно-моральним засадам.

Класицистичний театр мав виконувати перш за все моральнодидактичну функцію: в основі колізії лежали зіткнення почуттів та обов'язку, особистого з громадським і державним, протистояння пристрасті і розуму (причому перемагати мало не перше, а друге начало), продукувались ідеї розумного влаштування життя.

Класицизм з його культами і пріоритетами сам по собі стримував розвиток комедійного жанру, що відображав нижчі сторони дійсності. Відповідно до класицистичних засад, комедія не могла торкатись високих ідей, важливих проблем, а мала б виконувати лише розважальні функції.

Однак завдяки геніальності французького драматурга Ж.-Б. Мольєра, який за способом художнього мислення залишався класицистом, комедія II половини XVII ст. досягла високого розвитку.

Саме Мольєр, який зумів синтезувати народну коміку 3 «ученою» ренесансною, піднявши ідейність комедійного жанру до трагедійного сприйняття життя, є творцем «високої комедії», що відкривала шлях до розвитку реалістичної драматургії. 
Комедія Мольєра, успадкувавши кращі традиції гуманістичної епохи, була повернута своєю актуальною проблематикою до сучасності, розвінчуючи соціальні потворності феодально-буржуазних засад.

Драматургічний хист Мольєра досяг розквіту в кращих його комедіях «Тартюф» (1664), «Дон Жуан» (1665), «Мізантроп» (1666), які розвінчували феодально-буржуазні устої, лицемірство святенників, показну добродійність, фальшиву набожність, що прикривали внутрішній цинізм, користолюбство, нахабність і підступність.

Кращу комедію драматурга «Тартюф, або ж Облудник» спіткала терниста доля, оскільки вона була спрямована проти лицемірних святош, що входили в таємну релігійну організацію «Товариство святих дарів», покровителькою якої була королева Анна Австрійська (саме вона змальована сентиментально-зворушливо у відомій сазі про мушкетерів О. Дюма).

I хоча розв'язка твору утверджує показну справедливість монаршої влади, неминучість земного покарання шахраїв і пройдисвітів, вона залишається трагікомічною, адже не перекреслює головного задуму автора - зобразити згубні наслідки сліпої довірливості до підступників і лицемірів, нагадати відому євангельську тезу: «Стережіться фальшивих пророків, що приходять до вас в одежі овечій, а всередині - хижі вовки. По їхніх плодах ви пізнаєте їх» [Матвія, 7, 15:16].

Мольєрівський Тартюф став прозивним образом, уособленням підступного лицеміра, що прикривається напускною святістю.

Мотив лицемірного святоші був популярним у літературі, зокрема і в слов'янських письменників: наприклад, образи Іудушки Головльова з роману «Пани Головльови» М. Салтикова-Щедріна, Йосипа Бичка $з$ драми М. Кропивницького «Глитай, або ж Павук» тощо.

Якщо в «Тартюфі» Мольєр розвінчує фарисейство святенниківкористолюбців, які намагалися владарювати в усіх сферах суспіль- 
ства, то в комедії «Дон Жуан» об'єктом сатири драматурга ставало феодальне дворянство.

В основу мольєрівської комедії ліг міф про Дон Жуана - фольклорного персонажа, що став традиційним образом у світовій літературі, великого грішника, спокусника жінок, який переступає через усі земні й небесні закони.

Першим у літературі до цього відомого в народних легендах персонажа звернувся у філософсько-релігійній драмі барокового плану «Севільський дурисвіт, або Камінний гість» іспанський драматург Тірсо де Моліна. До теми Дон Жуана звертатимуться згодом немало митців: свої літературні версії написали К. Гольдоні, Е. Т. А. Гофман, С. Річардсон, Дж. Байрон, О. Пушкін, Жорж Санд, П. Меріме, О. К. Толстой, Леся Українка, Бернард Шоу, С. Черкасенко, музичні інтерпретації створили В. А. Моцарт, О. Даргомижський, Й. Штраус та ін.

Після п’єси про Дон Жуана Тірси де Моліни в епоху класицизму з'явилась одна з найкращих у світовій літературі художня інтерпретація цієї теми - комедія Мольєра, де по-своєму був трактований згідно з класицистичними принципами образ спокусника і богохульника: барокові настрої релігійно-філософського осмислення традиційних образів і сюжетів поступалися естетиці класицизму з іiі пріоритетами розуму, морального дидактизму, виразної соціально-етичної, громадянської спрямованості. Мольєр надав популярному мандрівному сюжету, який опановував сцени Свропи, оригінального сатиричного й соціального звучання.

П'єса, у якій мало комічного (по суті це серйозна комедія 3 глибоким трагедійним підтекстом), має передусім і класове спрямування в трактовці добра і зла, адже цинік, пройдисвіт, гвалтівник, відвертий богохульник і розпусник Дон Жуан є дворянином, аристократом. Саме ця кастова привілейованість дає йому можливість нахабно чинити будь-які переступи, викликані егоїстичними інстинктами й значною мірою ліберальними тенденціями філософії 
ренесансу $з$ iï підкресленою увагою до свобод і прав людини, до церковно-релігійного розкріпачення.

Мольєр у «Дон Жуані» більше, ніж в інших своїх комедіях, відступив від правил класицистичної естетики: не зберігається триєдність місця, дії і часу, характери не є однозначними, комічне й трагічне часто поєднуються.

Комедією, де трагедійне начало часто переважає над комічним, була наступна п’єса Мольєра «Мізантроп» - найулюбленіший твір самого автора. Власне, це різновид «високої комедії», $з$ донкіхотівськими мотивами.

Сила влади грошей, що стають імпульсом усіх конфліктів і протиріч, є наскрізною проблемою комедії Мольєра «Скупий», сюжет якої запозичений з п’єси давньоримського драматурга Плавта «Горщик».

Мотиви мольєрівського «Скупого» ми зустрінемо в літературі не раз: і в «Скупому лицарі» О. Пушкіна, і в бальзаківському папаші Гранде, i в образах глитаїв $з$ творів українських класиків I. Карпенка-Карого, М. Кропивницького, М. Старицького тощо (тут доцільно згадати знаменитий пушкінський афоризм із названого вище твору - вислів, що найкраще визначає суть культу наживи в будь-які епохи: «Ужсасный век, ужасные сердиа!»).

Остання визначна комедія Мольєра «Міщанин-шляхтич» (1670), що давно стала хрестоматійною, була написана в стилі комедії-балету (значну частину твору становлять балетні сцени: за вказівкою короля в п'єсу були введені турецькі танці).

Фабула твору досить послаблена, сама інтрига грунтується на прагненні буржуа Журдена, у домі якого відбувається дія, вибитись у вищий, аристократичний світ, стати дворянином.

Одержимий бажанням пристрасті, міщанин Журден перетворюється у жорстокого самодура.

Сюжет комедії Мольєра «Міщанин-шляхтич» послужив українському драматургові І. Карпенку-Карому для створення відомої п’єси «Мартин Боруля», а згодом мотиви мольєрівського 
твору мали місце у «філологічній» сатиричній комедії Миколи Куліша «Мина Мазайло».

Комедії Мольєра - визначне й непересічне явище в розвитку світової драматургії. Це був новий тип комедії, яка, успадкувавши кращі традиції античної та гуманістичної епох, досвід класицизму, була звернена як до сучасності з ії буржуазно-феодальними порядками, так і до наступних поколінь: адже людство і в інших соціальних формаціях зберігає свої пороки.

Епоха Просвітництва з їі культом розуму, ідеями буржуазної демократії, матеріалізму в осягненні природного середовища й водночас ідеалізму в соціально-етичних питаннях про облаштування світу, з вірою в розкріпачення людства шляхом наукового прогресу продукувала і відповідні естетичні засади в розвитку жанрів та жанрових різновидів.

Підйом буржуазії в ії боротьбі проти дворянства, проти феодальних устоїв висував на перший план героїв із демократичного, міщанського середовища. Відображення їх у літературі відтісняло на задній план представників аристократії. Водночас сатира розвінчувала пороки не тільки феодалізму, а й утверджуваного буржуазнодемократичного культу.

3 ідеями Просвітництва закономірно були пов'язані кращі комедії XVIII ст.: П. О. Бомарше «Севільський цирульник», «Шалений дань, або Весілля Фігаро» (Франція), К. Гольдоні «Слуга двох панів», «Хитра вдовичка» (Італія), Фонвізіна «Недоросль» (Росія), Р. Шерідана «Школа лихослів'я», «Дуенья» (Англія) та ін.

Своєю трилогією про кмітливого й хитрого слугу Фігаро («Севільський цирульник», «Весілля Фігаро», «Злочинна мати») Бомарше заявив про себе як чудового майстра комедії інтриги з оригінальними характерами, саркастичною загостреністю, емоційністю почуттів, викривальним пафосом, спрямованим проти аристократичного середовища.

Комедії Бомарше зі славою вийшли на сцени світового театру. За сюжетами його п’єс були написані опери «Весілля Фігаро» В. А. Моцарта і «Севільський цирульник» Дж. Россіні. 
Венеціанський драматург К. Гольдоні (1707-1793) проявив себе майстром «комедії характерів», замінивши шаблонні віджилі «маски» реальними, вихопленими $з$ життя персонажами.

Кращі комедії італійського драматурга («Слуга двох панів», «Хитра вдовичка», «Господарка готелю») живі й динамічні, з майстерно виписаними характерами, побутом, звичаями, національним колоритом. Вони мали безпосередній вплив і на розвиток української драматургії. Скажімо, мотив комедії Гольдоні «Слуга двох панів» послужив Г. Квітці-Основ $\square$ яненку для створення п’єси «Шельменко-денщик».

Дотепність, закручення інтриги, майстерність гумору, поляризація характерів, гострі морально-етичні проблеми часу - далеко не всі визначальні риси кращих комедій англійського драматурга Р. Шерідана, який ставив перед собою завдання не тільки повеселити глядача, а передусім виховати повагу до природних людських почуттів, до мужності та безкорисливості. Саме ці фактори є визначальними в п'єсі «Школа лихослів'я».

Взагалі в «Школі лихослів'я» Р. Шерідана поданий цікавий соціальний типаж конкретного середовища - тогочасного буржуазноаристократичного англійського суспільства. Лицемір Джозеф - це просвітницький варіант мольєрівського Тартюфа, перенесеного на інший грунт, у салон «благочестивої» леді Сніруел. Джозеф - людина-маска. Леді Сніруел - у минулому жертва лихослів'я, а в момент дії - його суб'єкт, одержимий злодіяннями.

Щирий і доброзичливий Чарльз, що певною мірою збивається 3 правильного шляху, людина чистого серця, чужа і неприйнятна в злополучній «школі лихослів'я».

Моралізаторські комедії Р. Шерідана, які тяжіли до класицистичних засад, пережили надовго свою епоху. Вони й сьогодні привертають театральну і читацьку увагу своєю дотепністю, майстерно виписаними характерами, контрастністю в дії й образах, вміло побудованою інтригою.

Непересічним явищем у розвитку комедійного жанру в просвітницьку епоху стали п'єси талановитого російського письменника 
єкатерининської доби Д. І. Фонвізіна (за висловом О. Пушкіна, «самый из нерусских русский»: прізвище походить від німецького Фон Візен, оскільки був нащадком старовинного рицарського роду 3 Лівонії) - творця російської побутової комедії, серед його творів найвідомішими стали «Недоросль» $\mathrm{i}$ «Бригадир».

П'єси Д. І. Фонвізіна започатковують розквіт класичної російської драматургії, зокрема комедійного жанру, засвідчуючи разом 3 тим проникнення в літературу творів, не передбачених класицистичною поетикою, розширюючи таким чином межі театральних репертуарів.

Хрестоматійна п'єса «Недоросль» - один із найбільш популярних творів Д. Фонвізіна, що відзначається особливою сатиричною спрямованістю і соціальною заглибленістю, самобутністю яскравих характерів. У класицистичну за формою комедію автор вкладає нові ідеї, привносить серйозні і зворушливі сцени, розширюючи можливості суспільної і політичної сатири, збагачуючи лексику влучними, завжди актуальними афоризмами соціальноетичного звучання («Корыстолюбие делает из человека такие же чудеса, как и любовь», "Начинаются чины - перестает искренность», «У кого чаще всех Господь на языке, у того черт на сердце», «Не хочу учиться, хочу жениться», «Вот злонравия достойные плоды», «Наука в развращенном виде есть лютое оружие делать зло» тощо).

Деякі образи (Митрофанушка, Скотінін) із комедій Фонвізіна стали прозивними.

Жанр «серйозної комедії» в епоху романтизму ознаменувала п'єса О. С. Грибоєдова «Горе $з$ розуму», яка стала непересічним явищем у розвитку російської драматургії.

Новопредставлена комедія Грибоєдова, звичайно ж, була пов'язана з попередніми комедійними традиціями, певною мірою класицистичними: тут збережений закон триєдності місця, дії, часу, ключовою $\epsilon$ морально-дидактична спрямованість, інтрига зав'язана на ряді випадковостей і т. ін. Зберігаються і традиційні 
комедійні атрибути: закоханий невдаха Чацький, розбещена увагою сентиментальна дівиця Софія, постійно обдурюваний усіма батько Фамусов, хитрий, везучий в житті й коханні Молчалін, винахідлива і спритна служниця Ліза, тупий солдафон Скалозуб тощо.

Однак самий ідейний зміст «Горя з розуму» виявився значно ширшим від традиційної фабули комедій.

Інтрига і боротьба, яку веде головний герой, відтісняються на другий план іншим протистоянням - протистоянням Чацького суспільству Фамусових, Молчаліних, Скалозубів, Решетилових та ін.

Комедія О. С. Грибоєдова «Горе з розуму» стала передусім сатирою на суспільні пороки, і не тільки свого часу. Сатиричні ознаки зумовили вплив і на композицію комедії, і на розвиток головної інтриги, яка загальмовується, поступаючись місцем довгим моралізаторським монологам. Конфлікт комедії Грибоєдова - це конфлікт різних ідейних світоглядів. Тому «Горе з розуму», беззаперечно, несе в собі ознаки драми ідей, яка значно пізніше, на межі XIX-XX ст., стане пріоритетною в розвитку світової драматургії, витісняючи на другий план традиційну реалістично-побутову п'єсу.

Жанрова своєрідність безсмертної комедії Грибоєдова відбилась і на ії трагікомічних особливостях. Трагікомічним (подібно до мольєрівського героя 3 «Мізантропа») виявився головний персонаж «Горя з розуму» Чацький - людина-інтелектуал, людина 3 іншого світу, якій немає місця серед товариства фамусових, молчаліних, скалозубів і їм подібних. Полум'яні монологи Чацького могли б скоріше озвучуватись у трагедії, але не в комедії.

Такий герой серед косності й пошлості антигероїв виглядає смішним - смішним наївністю, безкомпромісністю, нездогадливістю, невмінням приховувати свої щирі думки і почуття, необережністю, ідеалізмом. Необачлива поведінка Чацького вносить сум'яття в затхлу атмосферу фамусівського дому, який уособлює моральні болячки суспільства.

Трагізм становища інтелектуала Чацького окреслюється глибше ситуаціями, у які він попадає. Комічне, сатиричне, трагічне 
зливаються тут в одне ціле. I саме в цьому жанрова унікальність «серйозної» комедії О. С. Грибоєдова. Характерна для твору і глибока психологізація персонажів, що теж $\epsilon$ новаторством грибоєдовської комедії, так і «не розгаданої до кінця» (О. Блок).

Розвиток соціально-повчальної комедії в російській літературі XIX ст. знаходить продовження згодом у творчості М. Гоголя О. Островського, О. Сухово-Кобиліна, Л. Толстого й ін. У п’єсах цих спостерігається не тільки поглиблення характерів, поєднання трагічного з комічним, а й певною мірою завуальований філософський підтекст, нерідко й апокаліптичного характеру, як, скажімо, у «Ревізорі» М. Гоголя.

Геніальний сатирик Гоголь створив настільки смішну викривальну комедію соціального плану (ним був використаний мотив комедії Г. Квітки-Основ $\square$ яненка «Приезжий из столицы»), що ні сучасники, ні пізніші дослідники за розвінчувальним пафосом так і не змогли збагнути ії пророчого змісту. За майстерністю Гоголясатирика не помітили Гоголя-пророка, в образах-типах не побачили образів-символів. Власне, це була апокаліптична комедія.

Гоголівський Хлєстаков є прообразом грядущого антихриста. Дослідник Володимир Глянц, наприклад, підкреслює апокаліптичний зміст гоголівського «Ревізора», зазначаючи, що «Тип Хлестакова настоящее художественное открытие Гоголя - совершенно новый в русской да и мировой литературе, олицетворяющий не какие-то частные пороки, а сам дух последних времен» [Глянц 2004: 35].

Характерно, що у фіналі п'єси, коли для чиновників та обивателів міста так неочікувано розкривається обман, справжній Ревізор не з'являється на сцені. І в цьому також прихований гоголівський закодований реалізм: для всіх приходить час дати звіт за земні діяння істинному Ревізору - Вищому Судді: «Страшен тот ревизор, который ждет нас у гроба. Будто не знаете, кто этот ревизор? Что прикидываться? Ревизор этот - наша проснувшаяся совесть, которая заставит нас вдруг и разом взглянуть во все глаза на самих себя...» (М. Гоголь). 
Вплив «Ревізора» на розвиток комедійного жанру й сатиричної літератури загалом важко переоцінити. Витоки сатиричної типізації, яка йде від Гоголя, спостерігаємо в п'єсах українських драматургів І. Карпенка-Карого, М. Старицького, М. Кропивницького, у прозовій і віршованій сатирі російських та українських класиків.

Українська класична комедія, що бере витоки з інтермедійної частини шкільної драми та вертепу, в основному висвітлювала у XIX ст. соціально-побутовий спектр, родинні взаємини. У ній розвінчуються аморальність, крутійство, неуцтво, світ шахрайства i наживи. Кращі українські класичні комедії започатковані творчістю I. П. Котляревського (водевіль «Москаль-чарівник»), Г. КвіткиОснов $\square$ яненка («Сватання на Гончарівці», російськомовні «Приезжий из столицы», «Дворянские выборы», «Шельменко-денщик», «Шельменко - волостной писарь»). Пізніше, у II половині XIX ст., українська класична комедія в різних жанрових модифікаціях представлена творами М. Старицького («За двома зайцями» - сатирична комедія), І. Карпенка-Карого («серйозна» комедія «Розумний і дурень», сатиричні «Сто тисяч», «Хазяїн», пізніше - комедії дискусійного, ідейного плану «Суєта», «Житейське море»), М. Кропивницького («Чмир», «По ревізії»), I. Франка («Майстер Чирняк») тощо.

Нових рис (ускладнення характерів, інтерес до внутрішніх колізій, тяжіння до поглиблення психологізму, протистояння світоглядних орієнтацій) набуває жанр наприкінці XIX - поч. XX ст. в комедії ідей Бернарда Шоу, у комедії ідей і настрою Антона Чехова.

Англійський драматург-новатор ірландського походження, лауреат Нобелівської премії Бернард Шоу у своїй праці «Квінтесенція ібсенізму», апелюючи до критиків, які не звертають увагу на нову техніку популярних п'єс, зазначав: «Сьогодні наші п'єси, в тому числі й деякі мої п'єси, починаються з дискусій... П'єса без суперечки i без предмета суперечки більше вже не вважається серйозною драмою» [Шоу 1963: 69].

Великий драматург при цьому акцентував увагу й на інтелектуальній інтерпретації комедії чи драми загалом: «Справа в тому, 
що жоден нещасний випадок, навіть кривавий, не може лягти в основу справжньої драми, тим часом як суперечка між чоловіком i жінкою про те, де краще жити - в місті чи в селі, може стати відправною точкою жахливої драми чи блискучої комедї̈) [Шоу 1963: 71].

У кращих комедіях-дискусіях, драмах ідей («Пігмаліон», «Професія місіс Уоррен», «Людина і надлюдина», «Дім, де розбиваються серця») через внутрішні колізії Шоу втілює власні філософські концепції, трансформовані в пошуках ідеалу з атеїстичного, безбожницького начала, в ідеалістичні системи поступової перебудови світу на гуманістичних принципах, на появі благородних надлюдей, творців гармонії і щастя. Однак романтичні ілюзії, що випливають $з$ колізій п'єс Б. Шоу, виявляються смішними, вони терплять природний крах у зіткненні з реальною дійсністю, із сюрпризами життя.

Тут яскраво відчувається незаперечний вплив чеховської драматургії, серйозної комедії, часто з трагічним фіналом. Вплив Чехова-драматурга на свої п'єси, передусім на «Дім, де розбиваються серця», визнавав сам Б. Шоу, що, як і його російський колега по перу, самобутньо іронізував над романтичною екзальтованістю аристократії і буржуа, над ілюзорними облудами й одержимістю, навіть заснованих на благородних помислах.

Характерно, що саме російський драматург А. Чехов проявив новаторську зухвалість у визначенні жанру більшості своїх п’єс як комедій. Адже в п'єсах Чехова розв'язка може бути і трагічною, як, скажімо, у «Чайці». Однак суть «серйозної» комедії не завжди полягає в обов'язковій веселості (наприклад, у згадуваних вище мольєрівському «Дон Жуані» чи грибоєдовському «Горі 3 розуму» смішне поступається сумному): у таких творах, як правило, відображаються суперечності в людських характерах, істинні можливості яких не відповідають прагненням. I в цьому смисл іронізування над персонажами п'єс як Чехова, так і Шоу. Скажімо, у «Чайці» А. Чехова відчувається гірка іронія над людським чес- 
толюбством, над хворобливим прагненням самоствердження, над створенням героями віртуальної реальності, над псевдоестетикою, над модними мистецькими віяннями, позбавленими духовного начала. Убита Трепльовим чайка виступає символом мертвого естетизму, загиблого таланту, так і не зрозумілого, не реалізованого через віддаленість від живої дійсності, через декадентську оману псевдодуховності, створення вигаданого ілюзорного світу.

Ідейною домінантою символістичних комедій А. Чехова є іронізування над людськими пороками (гордістю, себелюбством, одержимістю модними віяннями, прагненням вибитись у вищий світ, бажанням змінити організацію суспільного життя, усталеної моралі, захопленням модними революційними, в основі своїй популістськими теоріями тощо) - пороками, що приводять до трагічних наслідків. Так, скажімо, одержимий прагненням слави, поглинутий створеною самим віртуальною реальністю Трепльов із «Чайки» застрелюється у фіналі твору (справді авторська зухвалість у визначенні жанру як комедії), а пишні фрази вічного студента Петі Трофимова із «Вишневого саду» («в некотором роде "Буревестник"»- I. Бунін) про нове життя («...и наши внуки и правнуки увидят ту новую жизнь»), про завдання людства в пошуках щастя, істини, гармонії - усе це майстерне, саме неповторно чеховське іронізування над ліберально-демагогічними деклараціями, які ні до чого не зобов'язують. Дисонансом цьому є фінальна метафора: старенький лакей Фірс залишається всіма забутий у чотирьох стінах. I в цьому суть утопічних ідей гуманізму, котрі в реальній дійсності терплять крах. Засновані на доктринах, де людина проголошується центром Всесвіту, як всесильна і вища понад усе, цінності гуманізму приречені.

Серйозні, власне сумні, комедії А. Чехова мали великий вплив на розвиток вітчизняної та й світової драматургії загалом (А. Афіногенов, Л. Леонов, О. Арбузов, О. Корнійчук, В. Розов, А. Володін, Л. Зорін, О. Вампілов, Б. Шоу, О. Кейсі, Е. Олбі, класики «театру абсурду» тощо). 
Традиції світової класичної комедії в різновидах новаторських пошуків були продовжені у XX столітті. Теми комедійного жанру диктуються тепер не тільки соціально-побутовими, суспільноморальними, а й передусім ідейно-політичними умовами. Ключовою ланкою численних жанрових форм і стильових варіантів при цьому стає універсальна категорія комічного в усьому розмаїтті: сатира, гумор, іронія, сарказм, гротеск тощо.

Зміст комічних конфліктів, характерів, ситуацій також зумовлений змінами в суспільному житті. Через домінування в художній свідомості XX ст. екзистенційного протиборства людини зі світом часткові недосконалості характерів та обставин менше турбують драматургів. Унаслідок цього трагікомічне світовідчуття стає часто домінантним для всього комедійного жанру XX століття.

Трагікомічне начало стає визначальним у комедіях мороку $\mathrm{i}$ хаосу, ексцентріадах, театрі абсурду, де гірке споглядання людської і суспільної загалом деградації посилюється нерідко до безвиході (Ж. Жироду, Д. Хармс, Ж. Ануй, Е. Іонеско, М. Куліш). Тут яскраво простежуються проблема втрати ідеалів, ілюзій, всеохопний дух іронії по відношенню до персонажів, до подій, до моралі, до публіки, врешті й до самого автора та його творчості.

Багатьма жанровими різновидами була представлена вітчизняна комедіографія пореволюційного періоду. Увагу привертали новації в російській сатирі «Містерія-буфф», «Клоп» і «Баня» В. Маяковського, створені у гротескно-умовному стилі. Самобутністю відзначаються гротескні комедії з анекдотичними ситуаціями «Мандат» М. Ердмана і «Хулій Хурина» М. Куліша - п’єси, де використаний мотив гоголівського «Ревізора».

У жанрі соціально-побутової комедії працювали драматурги епохи соцреалізму М. Зощенко, Б. Ромашов, О. Корнійчук, С. Михалков, А. Салинський, І. Микитенко й ін.

Не всі ці твори витримали іспит часом. Скажімо, такі популярні колись комедії, як «Соло на флейті», «Дівчата нашої країни» I. Микитенка, «В степах України» О. Корнійчука (остання з назва- 
них п'єс відзначалась цікавими національними характерами), були продиктовані ідеологічними імперативами й виконували пропагандистські функції.

Справді новаторськими комедіями антиутопічного спрямування - творами, які відображали суспільне безумство постреволюційної епохи, були «Шарманка» російського класика А. Платонова та «Мина Мазайло» українського майстра М. Куліша.

У першій з названих комедій висміюються пошуки «комуністичного раю», утопічні надії на науково-технічний прогрес, на штучний інтелект, друга $є$ сатирою на радянське міщанство, на національний нігілізм, на інтернаціонально-шовіністичні та космополітичні елементи, на примітивізм українського відродження в стилі ідеократичного режиму.

Основою комедії-антиутопії А. Платонова є комічна алегорія і сатирична символіка. «Філологічна» комедія ідей М. Куліша «Мина Мазайло» відзначається майстерно виписаними характерамисвітоглядами, характерами-символами.

У II половині XX ст. в розвитку вітчизняної комедіографії має місце жанр героїчної комедії, де комічне переплітається 3 романтичним, а патетика співвідноситься з гумористичними елементами (прикладом може бути «Весілля в Малинівці» Л. Юхвіда, «На світанку» Г. Плоткіна). Сміливим підходом до розвінчання негативних явищ суспільного життя, зокрема до висміювання паразитичного існування партійно-державної номенклатури, віддаленої від народу, відзначалася популярна сатирична комедія українського письменника В. Минка «Не називаючи прізвищ». На початку 60-х років у театрах України та й союзних загалом стала популярною химерна комедія О. Коломійця «Фараони», де використано і модифіковано прийоми травестії та буфонади, де переплітається сатиричне з ліричним, комічне з сумним, викривальне з морально-дидактичним.

Комедія «Фараони» О. Коломійця - справді непересічне явище в розвитку вітчизняної драматургії. 
Популярними на сценах театру і в кінематографі стають у II половині XX ст. ліричні комедії, часто 3 мелодраматичними елементами. Серед них досить відомі в читацькому й глядацькому світі «Куховарка» («Стряпуха») А. Сафронова, «Пора жовтого листя» М. Зарудного, «Перед вечерею» В. Розова (остання з названих відзначається психологічною акцентацією) тощо.

Цікавими в новаторських пошуках можна вважати комедії білоруського драматурга А. Макайонка «Затюканий апостол» (комедія-памфлет), «Дихайте економно» (комедія-антиутопія), О. Арбузова «Старомодна комедія» (комедія з мелодраматичним началом), О. Вампілова «Старший син» (лірико-психологічна комедія).

3 розвитком кінематографа комедійний жанр стає одним із найпопулярніших у кіно й телебаченні (часто це телеспектаклі переміщення зі сцени на екран). Серед кращих варто назвати ті, що пройшли по більшості екранів світу, зокрема «В джазі тільки дівчата» Б. Уайлдрера (за участю зірки Голлівуду Мерлін Монро), «Шлюб по-італійськи» Вітторіо де Сіки з виконавцями головних ролей Марчелло Мастрояні і Софі Лорен, «Дні кохання» Джузеппе де Сантиса за участю Марини Владі і Марчелло Мастрояні, «Цей шалений, шалений, шалений світ» Стенлі Крамера тощо.

3 вітчизняних кінокомедій чи не найбільшою популярністю $і$ сьогодні користуються такі шедеври радянського кіно, як «Свинарка і пастух» I. Пир $\square$ вва, «Волга-Волга» Г. Александрова, фільми Леоніда Гайдая («Діамантова рука», «Дванадцять стільців» (за однойменним романом Ільфа і Петрова), «Кавказька полонянка», «Операція И», «Афоня»), Ельдара Рязанова («Карнавальна ніч», «роноя долі, або 3 легким паром», «Службовий роман», «Про бідного гусара замовте слово», «Небеса обітовані» - дві останні більше тяжіють до трагікомедії) та ін.

На жаль, за останні десятиліття у зв'язку з розвитком глобалізму стираються національні фактори у світовій культурі, що безпосередньо має вплив на поступове викорінення традиційних елементів у літературі, театрі, кіно. Звідси і збіднення театраль- 
них і кінематографічних репертуарів: прадавні традиційні жанри, не поповнюючись і не збагачуючись новим, витісняються попскультурою.

\section{БІБЛІОГРАФІЯ}

Глянц 2004 - Глянц В. Гоголь и Апокалипсис / Владимир Глянц. - М., 2004. $328 \mathrm{c}$.

Матвія-Матвія, 7, 15:16.

Шоу 1963 - Шоу Б. О драме и театре / Бернард Шоу. - М., 1963. - 496 с. 